\title{
REFLECTIONS ON INTERNATIONAL ENGAGEMENT AS EDUCATIONAL DEVELOPERS IN THE UNITED STATES
}

Virginia S. Lee, Virginia S. Lee \& Associates

An important aspect of the increasing complexity of the higher education landscape is its gradual internationalization. However, neither our colleges and universities nor we as educational developers have unequivocally embraced internationalization. In this chapter, I offer examples of international engagement and a framework for thinking about them. I argue that international engagement in the form of an evolving global scholarship and practice of educational development represents the ultimate extension of our thought and practice as educational developers.

Since the founding of the Professional and Organizational Development Network in Higher Education (POD) in 1976, the higher education landscape has changed greatly. As student enrollments in colleges and universities have increased, higher education has become more democratized, and today's student body includes more first-generation college students, more students of color, and more nontraditional students than ever before. The assessment movement has caught hold, and with it has come a growing demand for accountability from the American public as so-called consumers of higher education. Simultaneously the academic disciplines have evolved, and new fields of study have appeared, including alternative epistemologies arising from feminism, African American studies, critical theory, postmodernism, and multidisciplinary approaches. Instructional technologies have become more pervasive and varied (Lee, 2010). And economic downturns have challenged institutions to do more with less.

An important part of the increasing complexity of the higher education landscape is its gradual internationalization, which mirrors the growing globalization of contemporary American society (for the distinction 
between globalization and internationalization, see Altbach \& Knight, 2007). However, colleges and universities have not unequivocally embraced internationalization. On the one hand, the number of international students rose to 671,616 in $2008-2009$, an 8 percent increase over the previous year. The increase in Chinese students was particularly notable: a 21 percent increase overall, with an impressive 60 percent increase at the undergraduate level (Fischer, 2009). Rapid development in China has created a demand for higher education that its own university system is still unable to fulfill. At the same time, the weakness of the dollar relative to other foreign currencies has made American higher education more affordable, and institutions are aggressively marketing their programs to international students. The number of colleges and universities offering degree programs and opening branches abroad has also increased, although the actual number of branches is not well documented. (The American Council of Education, 2009, sent surveys to 88 institutions reportedly operating 197 branch campuses abroad, but received responses from only 20 institutions with information on 40 branch campuses.) Enrollment in study-abroad programs has continued to increase. In 20072008, 262,416 American students studied abroad, an 8.5 percent increase over the previous year. And in a recent study, 83 percent of institutions surveyed indicated they wanted to send more students abroad and were taking measures to do so (Institute of International Education, 2009). Finally, in its publication College Learning for the New Global Century, the Association of American Colleges and Universities (2007) describes the essential student learning outcomes of its LEAP campaign including the following under Personal and Social Responsibility: "civic knowledge and engagement-local and global" and "intercultural knowledge and competence."

Yet despite the rising foreign demand for U.S. higher education, only 39 percent of institutions in 2006 made specific reference to international or global education in their mission statements. And fewer institutions required a course with an international or global focus as part of the general education curriculum in 2006 (37 percent) than five years earlier in 2001 (41 percent; Green, Luu, \& Burris, 2008). Similarly, American students' own interest in acquiring knowledge about other countries and cultures, either through study or actual experience, is tepid. Although 91 percent of American institutions offer study-abroad opportunities, only 1.4 percent of approximately 18 million students study abroad. Furthermore, although enrollments in foreign language courses increased steadily during the 1960-2002 period, total enrollments in U.S. institutions of higher education increased more rapidly. As a result, in 2002 
only 8.6 percent of students studied a foreign language compared to 16.1 percent in 1960 (Welles, 2004). Finally, Hayward (cited in DeZure, 2003, pp. 43-44) concludes that postsecondary graduates are poorly informed about other countries, consistently underperforming compared to students from other developed countries on global competency and geographical surveys.

Consequently, at a time when foreign demand for American higher education is rising and the world is flattening, the response of American higher education and its student body to the fact of globalization is ambivalent at best. The ambivalence is one manifestation, I believe, of widespread complacency due to our persistent sense of separation from the rest of the world and of invulnerability as the dominant world power in the past century. But our sense of separation and domination is an illusion. It took events as dramatic as the fall of the World Trade Towers on September 11, 2001, and the global financial crisis to shatter illusions of separation and domination, if only for a moment. The magnitude of our collective shock, bewilderment, and outrage - to foreign attack and our own Trojan horse of easy credit gifted to the rest of the world-was in direct proportion to the magnitude of our complacency. Something unshakable in the American psyche had been severely shaken.

\section{International Engagement as Educational Developers: Representative Examples}

Globalization is a fact: whether as citizens or educational developers, we are so embedded in an international context that, like the "American" car, the very distinction between domestic and foreign seems specious. The relevant question clearly is not, "Should we engage internationally?" but "How much?" and "How?".

In my role as POD president and as an independent consultant, I have had several opportunities to engage internationally: a two-week residence as a senior visiting fellow in educational development at the University of Windsor in Canada (September 2007); as program chair of the International Consortium for Educational Development (ICED) 2008 Conference in Salt Lake City, Utah and as POD representative to the ICED Council (June 2008); a week-long consultation at a Canadian college in Doha, Qatar (December 2008); as POD representative to the ICED Council meeting in Dublin, Ireland (June 2009); and as an invited keynote speaker, panelist, and workshop presenter at a national conference on educational development in Beijing, China (July 2009). Through these experiences, as well as my participation in POD leadership and governance, I have 
observed various modes of engagement in international contexts. These modes of engagement in turn reflect underlying assumptions about the mutual roles and expectations of and between our international counterparts and us. A few examples follow.

\section{Example 1: The Relative Importance of International Engagement in POD's Strategic Plan}

In recent executive and core committee meetings, we have had several discussions regarding the importance of international engagement in POD's strategic plan. Often international engagement is represented as a separate sphere of activity from services to members, professional development, and organizational development, with the obvious implication that use of resources for international engagement necessarily means fewer resources for other areas. We have also discussed whether "international" is a form of diversity and, if so, whether it is on equal footing with other forms of diversity, such as race, ethnicity, or sexual orientation. Two practical implications of these discussions are whether POD should be represented on the ICED Council and with what (if any) POD funding; and whether we should designate the Institute for New Faculty Developers, the International Institute for New Faculty Developers, what the latter designation signifies, and what (if anything) it promises in the way of special programming.

\section{Example 2: Being an Expert on Educational Development in International Contexts}

The growing importance of higher education in Asia, the Middle East, and other parts of the world has created a growing interest in educational and, more broadly, academic development. Not only are universities in these areas increasing the number of faculty members to accommodate a growing student body, they are also seeking ways to develop the professional capabilities of their faculties in teaching, research, and administration. As a result educational developers from the United States, United Kingdom, Canada, Australia, and other developed countries are increasingly called on to share their expertise with colleagues in the developing world.

What mutual expectations and assumptions underlie these consulting relationships? In July 2009, seven POD members joined colleagues from Australia, Hong Kong, and Norway as invited keynote speakers, presenters, and panelists at an educational development conference in Beijing, China. The conference was a staging event for the founding of a faculty 
development network in China. The structure of the conference-a mostly unilateral sharing of educational development ideas, concepts, and practices developed in Western contexts with a largely passive Chinese audience-embodied a clear set of assumptions about knowledge and technology transfer: the expectation that those who knew more assisted those who knew less, presumably to become more like themselves; the universality and generalizability of concepts such as educational development, leadership, and mentoring; and the related irrelevance of cultural, organizational and linguistic context.

It was hard to know whether attempts to deviate from these assumptions were successful. Wishing to engage participants more, was it acceptable for presenters to change the conference plan when the program had been carefully vetted through unknown authorities during the entire planning process? And the response to periodic opportunities for active engagement, a sacred cow in Western contexts, was mixed. Some conference delegates participated enthusiastically, while others took a break or seemed distracted. Report-outs from small group discussions were somewhat chaotic; for example, group spokespersons seemed reluctant to relinquish the floor once they had it. And we later learned that concepts such as leadership and mentoring did not translate readily into the Chinese context. I left feeling the conference had been important as a symbolic staging event, but wondered how we might do it differently the next time.

\section{Example 3: Exporting a Western Curriculum to a Non-Western Context}

When U.S. institutions establish degree programs and branch campuses overseas, American instructors often teach the curriculum to a non-American student body. The question arises, To what extent is a curriculum culturally neutral? To the degree that the curriculum is not neutral, who makes the accommodation-curriculum designer, instructor, student-and what does that imply?

In December 2008 I consulted with a Canadian college in Qatar with Canadian instructors teaching a Canadian curriculum in technical subjects to a Qatari student body. I observed instructors making on-the-ground adjustments to accommodate an array of unforeseen issues, including the communication abilities of students whose native language was not English; challenges in motivation due to the wealth of the students' families and the assurance of employment regardless of academic performance; students' extensive familial obligations; the importance of social interaction; the 
novelty of gender-integrated classes in a radically segregated society; and the relevance of the curriculum to students' future employment (for example, in the petroleum industry). In addition, the concept of education is still new in a tiny country whose traditional fishing and pearl hunting culture was displaced only in the $1940 \mathrm{~s}$ by the discovery of vast oil reserves off its coast.

\section{International Engagement as Educational Developers: A Framework}

The concept of elasticity of practice provides a useful bridge between the different modes of international engagement noted above. According to Carew, Lefoe, Bell, and Armour (2008), elastic practice describes "the process of tailoring a specific approach or instance of Academic Development from the full professional 'toolkit' (techniques, experiences, ideas, values, theories) that academic developers collect during their evolution as practitioners." In the process, "multiple theoretical bases are melded or successively employed to support an adaptive, responsive approach to practice" (p. 1). Elasticity of practice is relevant at any level of professional engagement, from our own academic department to the international arena. For educational developers, the hypothetical decision not to engage internationally would represent extreme inelasticity of practice and a mode of engagement here called isolationism. It mirrors the national policy of the United States of a similar name between the two world wars and still exerts a strong pull on the American psyche.

Within POD (see example 1), isolationism as a response to globalization reflects one way of resolving the tension between the traditional values and priorities of POD and the demands of a new higher education context (Lee, 2008a). For some, our historic commitment to the provision of services to our largely domestic membership, as articulated in the POD 2007/2012 Strategic Plan (POD, 2006), presents a conflict for resources with international engagement. However, given the fact of globalization today, support of international engagement is not inconsistent with continued strong support of our membership (goal 1), professional development (goal 2), organizational development (goal 3), or diversity (goal 5). Internationalization is a reality on our campuses, and because we are the largest and one of the most well-established educational development networks in the world, international colleagues attend our conferences and institutes for new faculty developers and regularly seek our counsel regarding educational development initiatives in their own countries. Engaging internationally provides a good example of how 
we are reinterpreting a traditional value of collegiality and service to our members and making it responsive to the current context.

Leaving the extreme inelasticity of isolationism, I consider two other modes of international engagement: colonialism and postcolonialism (Manathunga, 2006). In an international context, the colonialist mode of engagement is common and more readily visible in our interactions with colleagues in developing countries (see example 2). It is more elastic than isolationism, because there is at least some stretching of practice to acknowledge an international colleague. Within the colonialist perspective, we as American educational developers view the international colleague as an entity to be developed. The desire to develop the international colleague may be superficially benign, a genuine and seemingly disinterested desire to help the international colleague become "better" (often meaning "more like ourselves"). That is, our international colleague is like ourselves, except that she or he is at an earlier stage of development. I call the desire benign and disinterested because there is no explicit intention to develop the international colleague at his or her expense, serve an agenda of imperialist domination, or hold the colleague in a bond of obligation and dependency. There is also a comfortable clarity in the mutual roles and expectations of this perspective.

But the mode of engagement is more insidiously colonial, because it ignores (or only vaguely acknowledges) cultural context and, thereby, the identity of the international colleague as truly other. Manathunga (2006) asserts that the hegemony of educational psychology in educational development and its focus on universal and generalizable principles of learning and development within the individual partly supports the colonialist perspective. She also points to a celebratory and progressive liberal ideology that blithely ignores difference in the spirit of we-are-all-the-same. A practical implication of the colonialist perspective is a still relatively inelastic practice with no accommodation to the otherness of the international colleague because the otherness is still largely unseen. If accommodation occurs, the onus lies with the international colleague. To the extent that both parties are complicit in the mutual expectations of this perspective, however, the international colleague has little.permission to accommodate.

Within the postcolonial perspective, as educational developers we engage more critically and with greater awareness with the international other(see example 3). As a result, our practice becomes far more elastic as we adapt our existing toolkit to accommodate the needs and perspectives of the other. To a far greater extent than in the example above, we see instructors at the Canadian college in Qatar taking a colonial mode 
of engagement (that is, the export of a Canadian curriculum) and adapting it over time as they learn more about the needs and capabilities of their students. In contrast to the clarity of roles and expectations in the colonialist perspective, in our postcolonialist interactions with international colleagues, we move into a "contested, unstable space" where "identities can be explored, interrogated, problematized, blurred and engaged with and cultural change may take place" (Manathunga, 2006, p. 21). In the process, all of our conventions, comfortable truisms, and tidy categories-for example, learner centeredness, student engagement, academic time on task-are open to scrutiny and critique. Likewise, the international other needs to be willing to enter the same space with us. For example, the Qatari students need to give up notions of authority and the expectation of passivity in the colonial mode of engagement in order to engage in the learning process. Together we create a unique adaptation of our practice to the demands of a particular cultural context. In the process, our practice as educators and educational developers becomes increasingly flexible, nuanced, and sophisticated.

\section{International Engagement as Educational Developers: Levels of Engagement}

Thinking of the progressive levels of our engagement as educational developers, moving from the academic department through the institution and beyond, international engagement represents the last practical level of activity (Macdonald, 2009). Offering the most novel of experiences, international engagement is also the maximal test of the fundamental premises of our practice (Smith, 2009) and its flexibility, and, arguably, it offers the greatest opportunity for growth, both personally and collectively. Table 22.1 summarizes selected activities at each level of activity-department, institution, nation, globe-as well as possible conflicts that may arise and need to be resolved at each level. The conflicts are the "contested, unstable spaces" (Manathunga, 2006) that also represent opportunities for the growth and development of our practice. Each level necessarily encompasses the activities and conflicts of the previous levels and their resolution.

I believe the most compelling challenge at the global level-the most elastic extension of our practice-is the articulation of a meaningful and practical agenda for international educational development that at once incorporates and transcends the interests of individual nation states. The Bologna Declaration-an effort to strengthen the European higher education area by making academic degree standards and quality 
Table 22.I. Representative Activities and Conflicts at Different Levels of Engagement in Educational Development

Level

Department or school

Institution

Nation
Representative Activities

Course and curriculum design

Course and program assessment

Work related to disciplinary accrediting bodies

Peer review

Chair development

General education and other campuswide program reform efforts

Student retention and graduation

Addressing rising enrollments with fewer resources

Roles and rewards

Articulating educational agenda, including student learning outcomes that address the national agenda

Advocacy on behalf of the value of educational development

Advancement of own educational development research and practice agenda

Increasing visibility of self and institution through conference presentation and publication

Service and leadership in national organizations and initiatives
Representative Conflicts

Content versus learner orientation

Common understanding of the discipline, student learning outcomes Reconciling conflicting demands of disciplinary or regional accrediting body and institutional requirements

Negotiating the relationship between general education and the major

Balancing conflicting demands of teaching, research, service; allocation of resources, including time

Balancing effective teaching practices with higher facultyto-student ratios

Balancing national commitments and needs of own campus

Resolving conflicts of what is in the national interest with respect to higher education

Balancing autonomy of institutions and federal standards of accountability

Articulation of common values among different institution types in national organizations

In external work, accommodating to requirements of different institution types 
Globe

Articulating an interna-
tional agenda for edu-
cational development
Assisting emerging edu-
cational development
networks
Sharing approaches to
educational develop-
ment across national
borders through
international organi-
zations, conferences,
publication

Resolving problems of communication due to language differences, uses of different terminology, variations in national context, and cultural norms

Reconciling international and national educational development interests

Balancing commitments to one's own institution, national and international networks

assurance standards more comparable and compatible throughout Europe-represents the most relevant existing experiment in this direction. The primary impetus for the declaration was to ensure mobility and employability throughout Europe and to improve international competition and the attractiveness of European higher education throughout the world (Clement, McAlpine, \& Waeytens, 2004). Countries in Europe had to recognize that they had a larger, more critical interest that was better served by acting collectively rather than individually and that higher education was a critical piece of the equation. Analogously, given the fact of globalization and the related inconvenient truths of global warming, financial interdependence and instability, and the fragility of international peace and security, we may realize that as a globe, we ultimately share a set of interests far more critical than our competitive advantage relative to other nations and that here too, education is a critical piece of the equation.

\section{Recommendations and Conclusions}

Implicit in a global scholarship and practice of educational development is a tension between our individual efforts as educational developers, bound by local cultural and societal contexts, and the larger landscape of educational development worldwide. On the one hand, a global scholarship and practice of educational development acknowledges local and national variations and promises a productive synthesis among them. It also posits a practice in which educational development is put to the service of a global agenda that transcends local boundaries and national interests (Lee, 2008 b). For us as educational developers, a global scholarship and practice 
of educational development represents the ultimate contested, unstable space and the ultimate extension of our thought and practice.

As we move into the final years of implementation of the 2007-2012 POD strategic plan, I encourage us to become clearer on our international interests and their importance relative to other activities and priorities of the organization. At the very least, we should strengthen our representation on the ICED Council, sending a clear message to our international colleagues that we value that commitment. We should find better ways of sharing the discussions within and activities of ICED with the POD membership. We should encourage publication by international colleagues in member journals such as To Improve the Academy and publication by our members in International Journal for Academic Development. We should include more POD conference sessions and To Improve the Academy articles related to the internationalization of the academy and its implications for educational development.

As representatives of the world's largest educational development network and the dominant world power, we will be called on by our international colleagues to share our expertise. International work places a special burden of thorough advance preparation to ensure that our efforts have real, as opposed to symbolic, impact. It also requires close collaboration between the consultant and her international hosts during the planning of the visit and clear communication as the dynamics of the visit unfold. An orientation to the higher education context, current educational development practices, and cultural traditions, expectations, and norms of the conduct of the host country relevant to anticipated work is essential. Educational development concepts such as faculty governance, mentoring, and leadership, developed in largely Western contexts, are not readily understood in other countries where higher education is far more centralized. Where English is the second language, a glossary of educational development terms is useful. Even in other English-speaking countries, such as the United Kingdom and Australia, terminology is often subtly different from American use, resulting in an illusion of comprehension or a vague haze of incomprehension in conversation, and clarification of terminology is advisable here as well. Excellent translation is essential depending on the level of English proficiency of the international hosts and participants. Sending written transcripts of keynote addresses and papers well in advance of the visit is important for simultaneous translation and for interactive sessions, exceptionally skilled translators are mandatory. Finally, early in-country practitioners of educational development, particularly those with English fluency, provide a bridge between practice in the United States and the 
host country; engaging them as collaborators during the planning and implementation phases of the visit is another excellent strategy. (Many of these recommendations come from a debriefing document prepared by the members of the international delegation to the 2009 Beijing Conference.)

To quote Ji Xianlin, the master of Chinese culture who died during the Beijing conference in July 2009, "Cultural exchange is the main drive for humankind's progress. Only by learning from each other's strong points to make up for shortcomings can people constantly progress, the ultimate target of which is to achieve a kind of Great Harmony" ("The reluctant master," p. 8).

\section{REFERENCES}

Altbach, P., \& Knight, J. (2007). The internationalization of higher education: Motivations and realities. Journal of Studies in International Education, 11(3-4), 290-305.

American Council of Education. (2009). U.S. branch campuses abroad. ACE Issue Brief. Retrieved from www.acenet.edu/AM/Template.cfm?Section=I nfoCenter\&TEMPLATE $=/ \mathrm{CM} /$ ContentDisplay.cfm\&CONTENTID $=34786$

Association of American Colleges and Universities. (2007). College learning for the new global century. Washington, DC: Author.

Carew, A. L., Lefoe, G., Bell, M., \& Armour, L. (2008). Elastic practice in academic developers. International Journal for Academic Development, 13(1), 51-66.

Clement, M., McAlpine, L., \& Waeytens, K. (2004). Fascinating Bologna: Impact on the nature and approach of academic development. International Journal for Academic Development, 19(2), 127-131.

DeZure, D. (2003). Internationalizing American higher education: A call to thought and action. In C. M. Wehlburg \& S. Chadwick-Blossey (Eds.), To improve the academy: Vol. 21. Resources for faculty, instructional, and organizational development (pp. 40-55). San Francisco: Jossey-Bass/ Anker.

Fischer, K. (2009, November 16). Number of foreign students in U.S. hit a new high last year. Chronicle of Higher Education. Retrieved from http://chronicle.com/article/Number-of-Foreign-Students-in/49142/

Green, M. F., Luu, D., \& Burris, B. (2008). Mapping internationalization on U.S. campuses: 2008 edition. Washington, DC: American Council on Education. 
Institute of International Education. (2009). Expanding study abroad capacity at U.S. colleges and universities. IIE Study Abroad White Paper Series No. 6. Retrieved from www.iie.org/Content/NavigationMenu/Research_and_ Evaluation/Study_Abroad_White_Papers/StudyAbroad_WhitePaper6.pdf Lee, V. S. (2008a, October). Presidential address. Presented at the POD Network/NCSPOD Conference, Reno, NV.

Lee, V. S. (2008b). Reflections on the 2008 ICED conference. HERDSA News, 30(2), 21.

Lee, V. S. (2010). Program types and prototypes. In K. H. Gillespie \& D. Robertson (Eds.), A guide to faculty development (2nd ed.). San Francisco: Jossey-Bass.

Macdonald, R. (2009). Academic development. In M. Tight, K. H. Mok, J. Huisman, \& C. Morphew (Eds.), The Routledge international handbook of higher education (pp. 427-439). London: Routledge.

Manathunga, C. (2006). Doing educational development ambivalently: Applying post-colonial metaphors to educational development? International Journal of Academic Development, 11(1), 19-29.

Professional and Organizational Development Network in Higher Education. (2006). 2007/2012 strategic plan. Retrieved from www.podnetwork.org/ about/strategic_plan.htm

The reluctant master. (2009, July 12). China Daily, p. 8.

Smith, K. (2009). Transnational teaching experiences: An underexplored territory for transformative professional development. International Journal for Educational Development, 14(2), 111-122.

Welles, E. (2004). Foreign language enrollments in United States institutions of higher education, fall 2002. ADFL Bulletin, 35(2-3), 7-26. 